\title{
Climate Change and Fruit-Picking Tourism: Impact and Adaptation
}

\author{
Jun Liu, ${ }^{1}$ Fan Chen, ${ }^{1}$ Quansheng $\mathrm{Ge}^{2}$ and Yunyun $\mathrm{Li}^{1}$ \\ ${ }^{1}$ School of Tourism, Sichuan University, Chengdu 610064, China \\ ${ }^{2}$ Institute of Geographic Sciences and Natural Resources Research, Chinese Academy of Sciences, All Datun Road, Chaoyang District, \\ Beijing 100101, China
}

Correspondence should be addressed to Yunyun Li; arina_scdxlyy@126.com

Received 17 March 2016; Accepted 3 October 2016

Academic Editor: Herminia García Mozo

Copyright (C) 2016 Jun Liu et al. This is an open access article distributed under the Creative Commons Attribution License, which permits unrestricted use, distribution, and reproduction in any medium, provided the original work is properly cited.

\begin{abstract}
The purpose of this work is to present phenology as a valid indicator and methodology for monitoring and assessing the impact of climate change on plant-based tourist activities. Fruit-picking has become a popular rural tourism activity worldwide. However, fruit maturity dates (FMD) have been affected by climate change (CC), which has in turn profoundly affected fruit-picking tourism activities (FPTA). In this paper, phenological data on the FMD for 45 types of plants in 1980-2012, dates for more than 200 fruitpicking festivals, and data on monthly average air temperature in 1980-2013 were used to assess the impact of CC on FPTA by wavelet and correlation analyses. The findings indicated that the study area had been significantly affected by CC. Prevailing temperatures at one or three months prior have a decisive influence on FMD. Among the 11 plants directly related to FPTA, the FMD of four were significantly advanced, while 6-7 were significantly delayed owning to increased temperature. Of the 11 FPTA, only two had realized the impact of CC and had adjusted festival opening dates based on dynamic changes. However, a considerable number of festival activities remained fixed or scheduled on the weekends.
\end{abstract}

\section{Introduction}

The phenophases of plants (such as flowering and changes in leaf coloration) have important ecological and economic significance. In the past, people would celebrate seasons when plants blossom and bear fruits by holding festivals and carrying out related events and activities. These forms of leisure and tourism activities have always been very popular. Examples include the cherry blossom festivals held in Japan and the United States (US), tulip festival in Netherlands, and narcissus festival in Austria. Nowadays, viewing the flowering and leaf coloration changes of ornamental plants and fruitpicking have become attractive tourism activities. These aspects of the agritourism industry are valued at trillions of dollars. Every spring, the National Cherry Blossom Festival in Washington attracts 700,000 visitors [1], while daily visitors viewing the cherry blossoms in Ueno Park of Tokyo, Japan, amount to hundreds of thousands. Likewise, the National Cherry Festival held from November to December in the town of Young in New South Wales, Australia, every year attracts thousands of visitors. In China, viewing peach blossoms is a tradition that has lasted more than a thousand years. Each year, the Peach Blossom Festival held in Longquanyi District, Chengdu, attracts more than four million visitors.

In recent years, an important activity of rural tourism in China is fruit-picking during seasons when fruits ripen. During these periods, previous bases for fruit cultivation have now become important places for fruit-picking. It is also a popular recreation and tourism activity worldwide for individuals to pick fruits from fruit-producing bases personally and then savoring them fresh. Such activities in China attract the participation of large numbers of tourists. These include the annual loquat harvesting festival in spring, watermelon, and grape picking festivals in summer and citrus festival in fall. Tourism revenue derived from fruit-picking activities has gradually become an important component of local farmers' incomes.

The Strawberry Festival of Tongzhou District, Beijing, was officially opened on March 22, 2013. The event brought more than 20,000 visitors to the district and its surrounding 
towns and villages daily, generating daily incomes that amounted to 1.3 million renminbi (RMB). The first Grape Festival of Daxing District, Beijing, held in 2015 welcomed thousands of tourists on the opening day. In the fall of 2014, Beiwu Town, located in the Shunyi District of Beijing, promoted fruit-picking tours within an integrated green and ecological zone occupying 3,000 mu (Chinese acre), attracting large numbers of tourists.

The Shanghai Citrus Festival is organized on Changxing Island and draws more than 100,000 tourists annually. That number comprises half of the island's total tourist arrivals per year. The mulberry-producing base in Chongming County, Shanghai, which hosts the annual fruit-picking of mulberry festival, has a cultivated area of $7,148 \mathrm{mu}$, annual output capacity up to 8,500 tons, and annual output value amounting to one hundred million RMB. The 2015 Grape Cultural Festival of Pancheng New Street, Nanjing, lasted half a month and received more than 130,000 visitors. The cumulative weight of grapes sold was 8.75 million kilograms, translating to sales revenue of 109 million RMB. The Lvshun Cherry Festival welcomed 220,000 visitors in 2011, reaping nine million RMB in ticket sales. In addition, 20,000 tons of sweet cherries were sold, generating total revenue of 280 million RMB.

Phenological studies indicate that plants are more sensitive to temperatures during the phenophases (flowering and fruiting dates) [2-4]. There is already existing literature [5] that made use of phenological observation data on the flowering and leaf coloration changes of plants to examine the impact of climate change (CC) on plants' phenophases and related tourism activities, such as viewing floral blossoms in spring [6-8] and red foliage of trees in fall [9]. Aono and Kazui [10] pointed out that the average full flowering date of Kyoto's cherry blossoms in 1971-2000 had been advanced by seven days compared to 1,200 years ago. As an adaptation strategy to CC and the induced effect of the flowering date being advanced, Japan set up a dedicated website which was set up in Japan to provide visitors with accurate forecasts for the durations of and locations for viewing cherry blossoms. On the other hand, existing literature does not contain studies in which phenological data on fruit maturation are used to study possible impacts of CC on fruit-picking tourism activities (FPTA), nor have any adaptive measures been made.

In this context, this paper used phenological observation data on fruit maturation and defined characteristics of CC within the study area as the basis to analyze the sensitivity of maturity dates to air temperature. In so doing, the aim was to determine the types of plants whose FMD are being affected by CC. Next, the relationship between air temperature and the various fruit-picking festivals' opening date was analyzed. We also examined whether FMD and fruit-picking festivals were aligned with trends in temperature fluctuations.

These findings were used as the basis to determine the possible impact that $\mathrm{CC}$ has on fruit-picking tourism, as well as to propose strategies that can help related operators adapt to CC. The study subject was fruit-picking festival, while Chongqing Municipality was selected as the study area because there is a wide variety of FPTA held there. This meant that the impact will be felt there greater and that the comprehensive tourism effect will be more prominently. We hope that the study will alert researchers to the economic significance of phenology.

These findings can provide a preliminary insight into the adaptability of tourism activities to $\mathrm{CC}$ and serve as an important scientific basis to understand the temporal and regional variations in seasonal plant-related tourism activities. Furthermore, they can also guide the adaptation of tourism activities to CC and improve the accuracy and risk estimates of the economic impact that CC has on the tourism industry, and help tourism policy makers formulate strategies that will help tourism activities adapt to CC.

\section{Study Area}

Chongqing, the largest city in southwest China, is located between longitude $105^{\circ} 17^{\prime}-110^{\circ} 11^{\prime}$ east and latitude $28^{\circ} 10^{\prime}-$ $32^{\circ} 13^{\prime}$ north. It is an important tourism center along the upper reaches of the Yangtze River (Figure 1). In 2014, it hosted a total of 349 million tourists and tourism revenue was more than 200 billion RMB. Among that, rural tourism comprised 80 million visitors and business income of 15 billion RMB. The industry generated related jobs for more than 600,000 people and helped 180,000 farmers out of poverty.

The scale of FPTA in Chongqing has enlarged in recent years and its development has reached a more mature stage. Consequently, the comprehensive benefits of 11 FPTA have become more significant. Such activities have gradually become an important source of rural tourism revenue, with related tourism incomes having exceeded one billion RMB since 2013. At the 2010 Grape Tourism and Culture Festival of Bishan District, there were 120,000 visitors on the opening day alone and the tourism revenue reached 5.2 million RMB. For the Loquat Tourism Cultural Festival of Dazu District, visitor arrivals for both 2012 and 2013 exceeded 300,000 per year.

\section{Materials and Methods}

\subsection{Data Sources}

3.1.1. Data on FMD. Data on FMD for 45 plant species at Chongqing's Beibei Station for the two time periods of 1980-1996 and 2003-2012 were obtained from the Chinese Phenological Observation Network (CPON). The network was established upon the advocation of Mr. Zhu Kezhen and now it has more than 30 stations. It has the largest number of field observation stations within China, most abundant observed species, and uninterrupted plant phenophase data over the longest period (Table 1).

3.1.2. Data on Fruit-Picking Festivals and Activities. Extensive searches were made on authoritative newspapers (including Chongqing Daily, Chongqing Evening News, and Chongqing Economic Times) and web sites (including People's Daily Online and Tencent's Dayu Online) for the periods OctoberDecember 2014 and January-February 2016. The purpose was to collate from these sources the opening dates for the various fruit-picking festivals. This resulted in more than 200 records. Next, the opening dates for each festival as documented by 

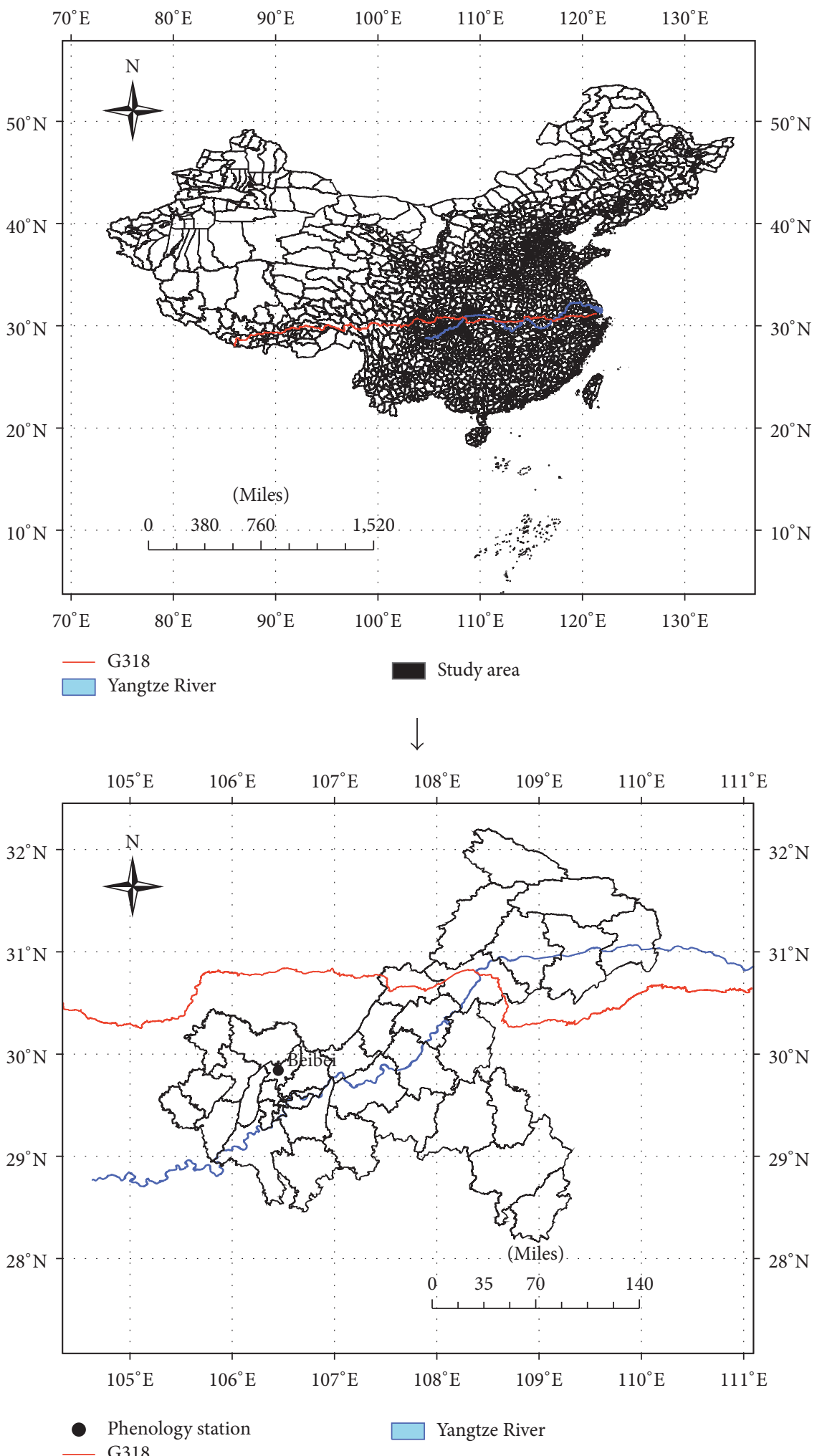

FIGURE 1: The spatial distribution of study area. 
TABLE 1: Summary of phenological data from the 45 species in Beibei during 1980-1996 and 2003-2012.

\begin{tabular}{|c|c|c|c|c|}
\hline Number & Species & Family & $N$ & FMD \\
\hline B1 & Michelia alba DC. (white Michelia flower) & Michelia & 5 & $8 / 24$ \\
\hline B2 & Cupressus funebris (Kashiwagi) & Cupressaceae & 12 & $9 / 2$ \\
\hline B3 & Platycladus orientalis (Platycladus orientalis) & Platycladus & 16 & $9 / 4$ \\
\hline B4 & Salix babylonica (Willow) & Salix & 11 & $4 / 22$ \\
\hline B5 & Robinia pseudoacacia (Locust) & Robinia & 23 & $7 / 3$ \\
\hline B6 & Ligustrum compactum Ait (Ligustrum) & Ligustrum & 21 & $11 / 2$ \\
\hline B7 & Citrus sinensis (Goose Orange) & Citrus & 12 & $11 / 13$ \\
\hline B8 & Pterocarya stenoptera (Chinese Wingnut) & Pterocarya & 10 & $8 / 1$ \\
\hline B9 & Broussonetia papyrifera (Paper Mulberry) & Broussonetia & 18 & $7 / 25$ \\
\hline $\mathrm{B} 10$ & Pittosporum tobira (Pittosporum) & Pittosporum & 15 & $11 / 4$ \\
\hline B11 & Camptotheca acuminata Decne (Camptotheca acuminata) & Camptotheca & 12 & $11 / 2$ \\
\hline B12 & Albizia julibrissin Durazz (Albizzia) & Albizzia & 8 & $8 / 2$ \\
\hline B13 & Lindera megaphylla Hemsl (Lindera megaphylla) & Lindera & 6 & $8 / 13$ \\
\hline B14 & Juglans regia (Persian Walnut) & Juglandaceae & 11 & $9 / 10$ \\
\hline B15 & Sophora japonica (Chinese scholar tree) & Sophora & 19 & $11 / 11$ \\
\hline B16 & Platycodon grandiflorus (Bellflower) & Campanulaceae & 13 & $10 / 22$ \\
\hline B17 & Chimononthus praecox (Winter Sweet) & Chimononthus & 4 & $5 / 28$ \\
\hline B18 & Ulmus parvifolia (Chinese Elm) & Ulmus & 16 & $10 / 29$ \\
\hline B19 & Prunus salicina (Plum) & Prunus & 12 & $6 / 18$ \\
\hline B20 & Podocarpus macrophyllus (Yacca) & Podocarpus & 14 & $7 / 6$ \\
\hline B21 & Spiraea salicifolia (Spiraea) & Rosaceae & 15 & $5 / 4$ \\
\hline B22 & Paulownia fortunei (Paulownia) & paulownia & 8 & $9 / 27$ \\
\hline B23 & Herba Ainsliaeae Lancifoliae (All-grass of Lanceleaf Ainsliaea) & Asteraceae & 5 & $9 / 22$ \\
\hline B24 & Malus pumila (Apple) & Malus & 13 & $8 / 4$ \\
\hline B25 & Vitis vinifera (Grapes) & Vitaceae & 21 & $7 / 16$ \\
\hline B26 & Acer buergerianum (Triangle Maple) & Acer & 6 & $8 / 11$ \\
\hline B27 & Morus alba (Mulberry) & Morus & 21 & $4 / 27$ \\
\hline B28 & Amygdalus davidiana (Mountain Peach) & Rosaceae & 11 & $6 / 18$ \\
\hline B29 & Punica granatum (Pomegranate) & Punica & 19 & $9 / 27$ \\
\hline B30 & Amygdalus persica (Peach) & Rosaceae & 15 & $6 / 17$ \\
\hline B31 & Firmiana platanifolia (Chinese parasol (tree)) & Firmiana & 17 & $9 / 4$ \\
\hline B32 & Cinnamomum camphora (Camphor tree) & Cinnamomum & 23 & $10 / 13$ \\
\hline B33 & Ligustrum quihoui (Purpus Privet) & Ligustrum & 12 & $10 / 9$ \\
\hline B34 & Platanus acerifolia (Planetree) & Platanus & 11 & $9 / 6$ \\
\hline B35 & Fontanesia fortunei (Fontanesia) & Fontanesia & 14 & $10 / 5$ \\
\hline B36 & Cerasus pseudocerasus (Cherry) & Cerasus & 9 & $4 / 13$ \\
\hline B37 & Vernicia fordii (Tung tree) & Vernicia & 12 & $10 / 27$ \\
\hline B38 & Firmiana simple (Phoenix tree) & Firmiana & 9 & $8 / 11$ \\
\hline B39 & Cercis chinensis (Chinese redbud) & Cercis & 21 & $8 / 24$ \\
\hline B40 & Wisteria sinensis (Wisteria) & Leguminosae & 10 & $7 / 21$ \\
\hline B41 & Lagerstroemia indica (Crape myrtle) & Lagerstroemia & 18 & $10 / 16$ \\
\hline B42 & Eriobotrya japonica (Loquat) & Rosaceae & 20 & $5 / 12$ \\
\hline B43 & Citrus maxima (Shaddock) & Citrus & 18 & $10 / 8$ \\
\hline B44 & Koelreuteria paniculata (Goldenrain tree) & Koelreuteria & 21 & $10 / 18$ \\
\hline B45 & Melia azedarach (Chinaberry) & Melia & 25 & $11 / 8$ \\
\hline
\end{tabular}

B1-B45 were species from Beibei. $N$, number of observation years; FMD denote timing of fruit maturity date. 


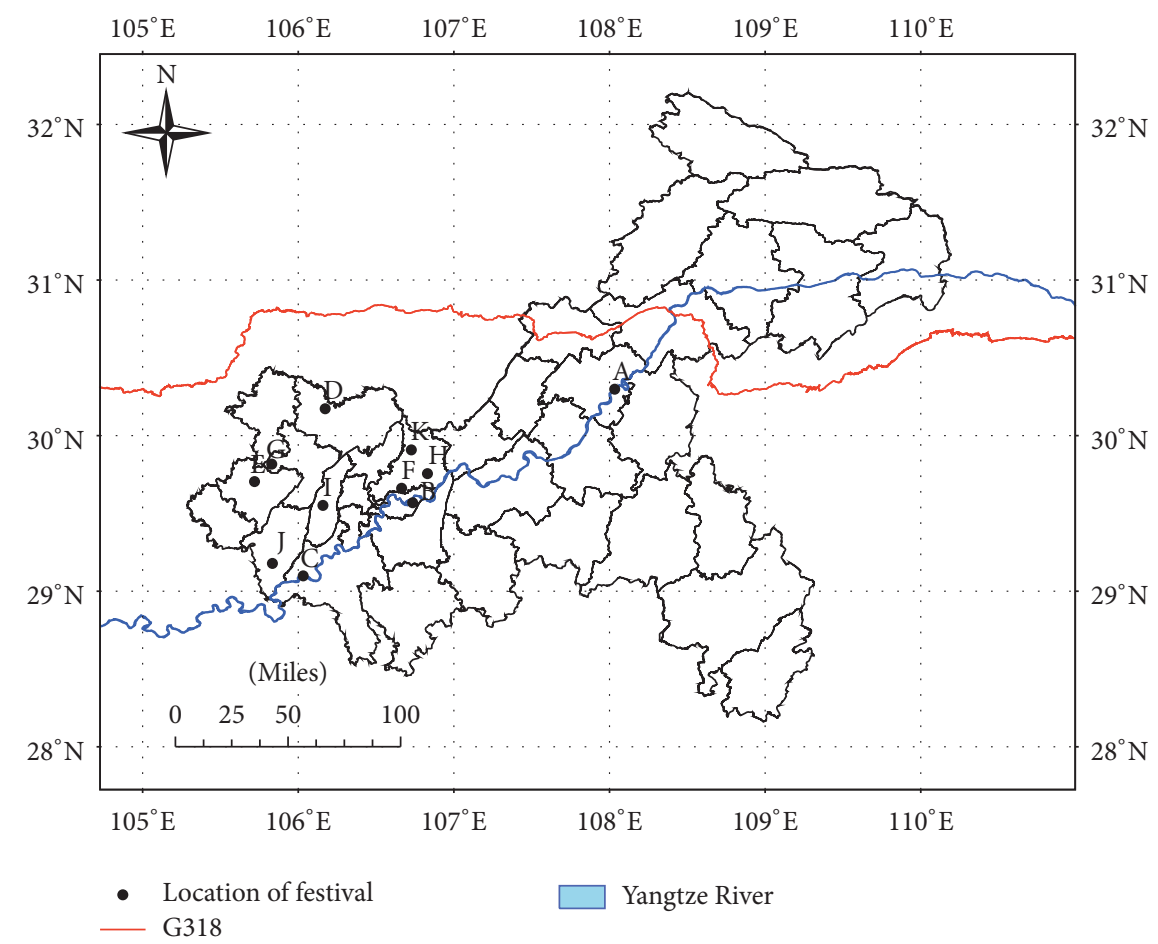

FIGURE 2: Location of fruit-picking tourism festival in Chongqing (A, Citrus Cultural Festival of Zhong County; B, Loquat Festival of Jiangnan District, C, Rural Tourism and Late Maturing Citrus Fruit-Picking Festival of Shimen Town, Jiangjin District, D, Loquat Fruit-Picking Festival of Gulou Town, E, Loquat Tourism Cultural Festival of Dazu District, F, Cherry Festival of Yufengshan Town, G, Cherry Festival of Shuangshan Town, H, Grape Festival of Sichuan Town, I, Grape Tourism and Culture Festival of Bishan District, J, Watermelon Tourism and Cultural Festival of Yongchuan District, and K, Waxberry Cultural Festival of Xinglong Town).

the different media were verified individually. Eventually, the sequences of dates for 11 types of FPTA were established (Figure 2).

3.1.3. Meteorological Data. Data on monthly average air temperature recorded at seven meteorological stations in Chongqing between 1980 and 2013 were acquired from Chinese Meteorological Data Online (http://data.cma.gov.cn/site/ index.html). The seven stations were Fengjie, Liangping, Wanzhou, Shapingba, Fuling, Youyang, and Beibei. The data were used to analyze the climatic trends in the study area. Separately, data on monthly average air temperature recorded at the Shapingba, Dazu, Hechuan, and Jiangjin Meteorological Stations between 2007 and 2015 were used to conduct correlation analysis with the opening dates of the various festivals.

\subsection{Methodology}

3.2.1. Analyzing Sensitivity of FMD and FPTA to Air Temperature Changes. Correlation analyses were made on a yearly basis between (i) the temperature sequence data at the Beibei Meteorological Station and (ii) phenological observation data on FMD for 45 plants. The purpose was to determine the degree of sensitivity of FMD to CC within the study area. Correlation analyses were also made between the opening dates of the various fruit-picking festivals and air temperature at the corresponding meteorological stations. This was to ascertain whether the operators of fruit-picking festivals had taken CC into consideration.

3.2.2. Analyzing Patterns of Cyclical Changes in Air Temperature. Since CC contains regional variations, it was necessary to confirm whether the study area had experienced CC. Wavelet analysis has the advantage of being able to determine the magnitude and timing of change for a time series and hence is widely used in climate diagnostics [11, 12]. Considering that air temperature is the most important factor affecting plant phenology, this paper applied the Morlet wavelet analysis [13] to study the patterns of cyclical changes in the air temperature for Chongqing.

\section{Results}

4.1. Significant Changes in CC in the Study Area. There had been significant cyclical changes in the annual average air temperature of the study area between 1980 and 2013. For the real-part isolines and norm time-frequency of the wavelet transform coefficients, the positive and negative centers represent air temperature on the high and low sides, respectively.

Overall, isolines for the annual average wavelet coefficients are relatively dense around the 4-7a, 8-16a, and 2632a temporal scales. Among these, the density for the 4-7 a temporal scale was the most prominent over the entire 
TABLE 2: Fitting equation of fruit maturity date and air temperature (T1) in Beibei.

\begin{tabular}{|c|c|c|c|c|c|c|}
\hline Number & Species & Family & Phases & Air temperature & Fitting equation & Adj. $R^{2}$ \\
\hline B4 & Salix babylonica (Willow) & Salix & FMD & $T 1$ & $y=3.21 x+58.24$ & $0.5962^{* * *}$ \\
\hline B5 & Robinia pseudoacacia (Locust) & Robinia & FMD & $T 1$ & $y=9.00 x-37.79$ & $0.5484^{* * *}$ \\
\hline B6 & $\begin{array}{l}\text { Ligustrum compactum Ait } \\
\text { (Ligustrum) }\end{array}$ & Ligustrum & FMD & $T 1$ & $y=-3.66 x+385.72$ & $0.6523^{* * *}$ \\
\hline B7 & Citrus sinensis (Goose Orange) & Citrus & FMD & $T 1$ & $y=-3.62 x+385.69$ & $0.8517^{* * *}$ \\
\hline B8 & $\begin{array}{l}\text { Pterocarya stenoptera (Chinese } \\
\text { Wingnut) }\end{array}$ & Pterocarya & FMD & $T 1$ & $y=10.26 x-48.06$ & $0.8536^{* * *}$ \\
\hline B9 & $\begin{array}{l}\text { Broussonetia papyrifera (Paper } \\
\text { Mulberry) }\end{array}$ & Broussonetia & FMD & $T 1$ & $y=9.13 x-31.59$ & $0.3658^{* * *}$ \\
\hline $\mathrm{B} 10$ & Pittosporum tobira (Pittosporum) & Pittosporum & FMD & $T 1$ & $y=-4.76 x+400.89$ & $0.6913^{* * *}$ \\
\hline B11 & $\begin{array}{l}\text { Camptotheca acuminata Decne } \\
\text { (Camptotheca acuminata) }\end{array}$ & Camptotheca & FMD & $T 1$ & $y=-3.66 x+375.38$ & $0.5007^{* * *}$ \\
\hline B12 & $\begin{array}{l}\text { Albizia julibrissin Durazz } \\
\text { (Albizzia) }\end{array}$ & Albizzia & FMD & $T 1$ & $y=13.10 x-126.28$ & $0.7522^{* * *}$ \\
\hline B13 & $\begin{array}{l}\text { Lindera megaphylla Hemsl } \\
\text { (Lindera megaphylla) }\end{array}$ & Lindera & FMD & $T 1$ & $y=-5.34 x+383.92$ & $0.7311^{* *}$ \\
\hline B14 & Juglans regia (Persian Walnut) & Juglandaceae & FMD & $T 1$ & $y=-4.44 x+377.57$ & $0.5319^{* * *}$ \\
\hline B15 & $\begin{array}{l}\text { Sophora japonica (Chinese } \\
\text { scholar tree) }\end{array}$ & Sophora & FMD & $T 1$ & $y=-0.13 x+58.58$ & $0.7604^{* * *}$ \\
\hline B16 & $\begin{array}{l}\text { Platycodon grandiflorus } \\
\text { (Bellflower) }\end{array}$ & Campanulaceae & FMD & $T 1$ & $y=-1.08 x+316.45$ & $0.3586^{* *}$ \\
\hline B17 & $\begin{array}{l}\text { Chimononthus praecox (Winter } \\
\text { Sweet) }\end{array}$ & Chimononthus & FMD & $T 1$ & $y=3.44 x+81.07$ & $0.7409^{*}$ \\
\hline B18 & Ulmus parvifolia (Chinese Elm) & Ulmus & FMD & $T 1$ & $y=-3.39 x+377.82$ & $0.4593^{* * *}$ \\
\hline B19 & Prunus salicina (Plum) & Prunus & FMD & $T 1$ & $y=5.11 x+59.53$ & $0.63^{* * *}$ \\
\hline B20 & Podocarpus macrophyllus (Yacca) & Podocarpus & FMD & $T 1$ & $y=9.38 x-40.89$ & $0.6622^{* * *}$ \\
\hline B21 & Spiraea salicifolia (Spiraea) & Rosaceae & FMD & $T 1$ & $y=3.32 x+67.83$ & $0.7254^{* * *}$ \\
\hline B22 & Paulownia fortunei (Paulownia) & paulownia & FMD & $T 1$ & $y=-2.32 x+325.95$ & $0.4433^{*}$ \\
\hline B23 & $\begin{array}{l}\text { Herba Ainsliaeae Lancifoliae } \\
\text { (All-grass of Lanceleaf Ainsliaea) }\end{array}$ & Asteraceae & FMD & $T 1$ & $y=-7.46 x+462.35$ & $0.6613^{* *}$ \\
\hline B24 & Malus pumila (Apple) & Malus & FMD & $T 1$ & $y=6.64 x+37.85$ & $0.7617^{* * *}$ \\
\hline B25 & Vitis vinifera (Grapes) & Vitaceae & FMD & $T 1$ & $y=3.43 x+109.13$ & $0.4004^{* * *}$ \\
\hline B26 & $\begin{array}{l}\text { Acer buergerianum (Triangle } \\
\text { Maple) }\end{array}$ & Acer & FMD & $T 1$ & $y=10.53 x-77.23$ & $0.6898^{* *}$ \\
\hline B27 & Morus alba (Mulberry) & Morus & FMD & $T 1$ & $y=5.85 x+23.36$ & $0.7597^{* * *}$ \\
\hline B29 & Punica granatum (Pomegranate) & Punica & FMD & $T 1$ & $y=-3.19 x+355.93$ & $0.4633^{* * *}$ \\
\hline $\mathrm{B} 30$ & Amygdalus persica (Peach) & Rosaceae & FMD & $T 1$ & $y=2.06 x+120.69$ & $0.2968^{* *}$ \\
\hline B32 & $\begin{array}{l}\text { Cinnamomum camphora } \\
\text { (Camphor tree) }\end{array}$ & Cinnamomum & FMD & $T 1$ & $y=-4.12 x+395.32$ & $0.6648^{* * *}$ \\
\hline B33 & $\begin{array}{l}\text { Ligustrum quihoui (Purpus } \\
\text { Privet) }\end{array}$ & Ligustrum & FMD & $T 1$ & $y=-19.07 x+623.30$ & $0.8315^{* * *}$ \\
\hline B35 & Fontanesia fortunei (Fontanesia) & Fontanesia & FMD & $T 1$ & $y=-5.52 x+418.43$ & $0.8808^{* * *}$ \\
\hline B37 & Vernicia fordii (Tung tree) & Vernicia & FMD & $T 1$ & $y=-1.18 x+328.35$ & $0.244^{*}$ \\
\hline B38 & Firmiana simple (Phoenix tree) & Firmiana & FMD & $T 1$ & $y=9.54 x-35.38$ & $0.6006^{* * *}$ \\
\hline B39 & Cercis chinensis (Chinese redbud) & Cercis & FMD & $T 1$ & $y=5.84 x+76.47$ & $0.2019^{* *}$ \\
\hline B8 & Wisteria sinensis (Wisteria) & Leguminosae & FMD & $T 1$ & $y=6.37 x+27.93$ & $0.7724^{* * *}$ \\
\hline B41 & $\begin{array}{l}\text { Lagerstroemia indica (Crape } \\
\text { myrtle) }\end{array}$ & Lagerstroemia & FMD & $T 1$ & $y=-3.64 x+373.20$ & $0.4625^{* * *}$ \\
\hline B42 & Eriobotrya japonica (Loquat) & Rosaceae & FMD & $T 1$ & $y=4.59 x+52.31$ & $0.4512^{* * *}$ \\
\hline B43 & Citrus maxima (Shaddock) & Citrus & FMD & $T 1$ & $y=-5.84 x+429.37$ & $0.5341^{* * *}$ \\
\hline
\end{tabular}


TABLe 2: Continued.

\begin{tabular}{llcccc}
\hline Number & Species & Family & Phases & Air temperature & Fitting equation \\
\hline B44 & $\begin{array}{l}\text { Koelreuteria paniculata } \\
\text { (Goldenrain tree) }\end{array}$ & Koelreuteria & FMD & Ad $R^{2}$ \\
B45 & Melia azedarach (Chinaberry) & Melia & FMD & $T 1$ & $y=-4.96 x+405.65$ \\
\hline
\end{tabular}

$\mathrm{T} 1$ denotes the average air temperature one month prior to fruit maturity date, where $*, * *$, and $* * *$ denote $10 \%, 5 \%$, and $1 \%$ significance levels, respectively.

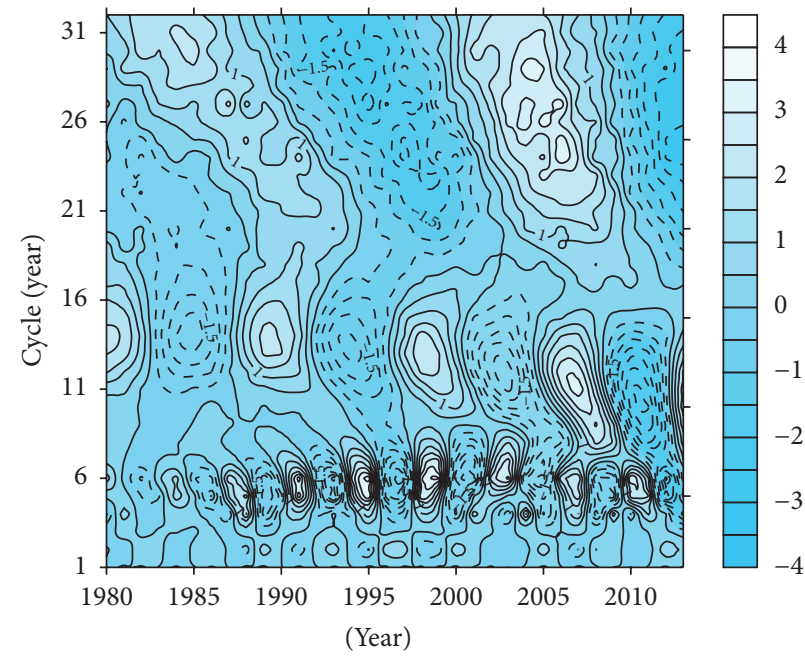

(a)

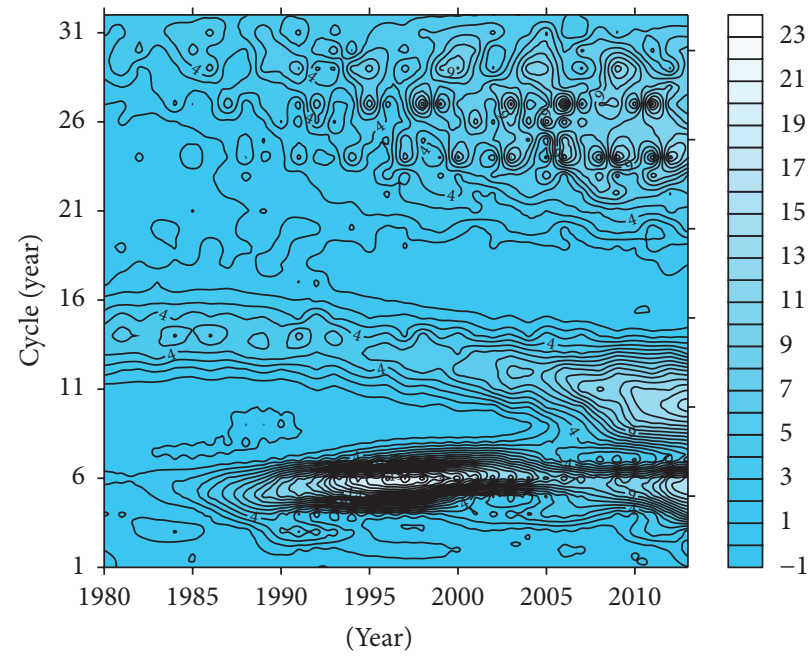

(b)

FIGURE 3: The isoline of the real part of wavelet coefficients, the norm time-frequency of wavelet coefficients of annual average air temperature.

study period (1980-2013). Its center temporal scale was approximately 6 a, during which temperatures underwent 8.5 alternating cycles of low $\rightarrow$ high $\rightarrow$ low $\rightarrow$ high. Next was the 8-16 a temporal scale, during which density was quite high. Its center temporal scale was approximately 6 a, during which temperatures underwent 3.5 alternating cycles of low $\rightarrow$ high $\rightarrow$ low $\rightarrow$ high. Last was the 26-32a temporal scale, with its center at 29 a (Figure 3(a)).

The norm time-frequency diagram of wavelet transform coefficients indicates that, among the three temporal scales, the cyclical oscillation during 4-7a was the strongest and had the widest coverage. These mainly occurred in 1981-2006, with the oscillation center at approximately 1998. The other cyclical oscillations were relatively weak (Figure 3(b)).

\subsection{FMD Are Highly-Sensitive to Air Temperature Changes.}

Temperature changes have significant impact on FMD, with different species having varying degrees of sensitivities. Of the 45 types of plants, 37 were sensitive to prevailing temperatures for the previous month (Table 2). Among these, the FMD of 20 plants were advanced due to rising temperatures, with the sensitivity range being $0.13-19.71 \mathrm{~d} /{ }^{\circ} \mathrm{C}$. For the four plants specifically related to fruit-picking, the sensitivity range was 3.19-5.84 $\mathrm{d} /{ }^{\circ} \mathrm{C}$. Pomegranate was the most sensitive, while shaddock was the least. On the other hand, the FMD of 17 plants were delayed due to rising temperatures, with the sensitivity range being $2.06-13.10 \mathrm{~d} /{ }^{\circ} \mathrm{C}$. The sensitivity range for the six plants related to fruit-picking was $2.06-6.64 \mathrm{~d} /{ }^{\circ} \mathrm{C}$, with apple and peach being the most and least sensitive, respectively.
Prevailing temperatures for the previous three months affected 38 plants (Table 3). Among these, the FMD of 16 plants were advanced. The overall sensitivity range and that for the four plants directly related to fruit-picking were 1.56$9.97 \mathrm{~d} /{ }^{\circ} \mathrm{C}$ and $4.18-7.23 \mathrm{~d} /{ }^{\circ} \mathrm{C}$, respectively. Pomegranate and cherry were the most and least sensitive, respectively. The FMD of the remaining 22 plants were delayed due to rising temperatures. The sensitivity range was $2.06-10.26 \mathrm{~d} /{ }^{\circ} \mathrm{C}$. Of these, the seven plants related to fruit-picking had a sensitivity range of $2.06-7.39 \mathrm{~d} /{ }^{\circ} \mathrm{C}$, with mulberry being the most sensitive and Mountain Peach the least.

4.3. Adaptation of FPTA to CC. Correlation analysis was made between 11 FPTA and monthly average air temperature one month prior to the respective opening dates of those activities. Only two fruit-picking festivals were significantly consistent with trends in temperature variations $(P<0.05)$ : (i) Cherry Festival of Shuangshan Town (Figure 4(b)) and (ii) Citrus Cultural Festival of Zhong County (Figure 4(d)). Of the remaining nine festivals, the opening dates for three were related to the previous month's temperatures $(P<0.1)$. These were the Loquat Tourism Cultural Festival of Dazu District (Figure 4(a)), Waxberry Cultural Festival of Xinglong Town (Figure 4(c)), and Grape Tourism and Cultural Festival of Bishan District (Figure 4(e)).

Specifically, rising temperatures led to the advance of the Cherry Festival of Shuangshan Town's opening date by $3.14 \mathrm{~d} /{ }^{\circ} \mathrm{C}$ (Figure $4(\mathrm{~b})$ ). The opening dates of the remaining four festivals were all delayed due to temperature increases, 
TABLE 3: Fitting equation of fruit maturity date and air temperature (T3) in Beibei.

\begin{tabular}{|c|c|c|c|c|c|c|}
\hline Number & Species & Family & Phases & Air temperature & Fitting equation & Adj. $R^{2}$ \\
\hline B1 & $\begin{array}{l}\text { Michelia alba DC. (white } \\
\text { Michelia flower) }\end{array}$ & Michelia & FMD & $T 3$ & $y=5.85 x+77.21$ & $0.7999^{* *}$ \\
\hline B2 & Cupressus funebris (Kashiwagi) & Cupressaceae & FMD & $T 3$ & $y=7.22 x+54.42$ & $0.616^{* * *}$ \\
\hline B3 & $\begin{array}{l}\text { Platycladus orientalis } \\
\text { (Platycladus orientalis) }\end{array}$ & Platycladus & FMD & T3 & $y=4.18 x+132.68$ & $0.385^{* * *}$ \\
\hline B4 & Salix babylonica (Willow) & Salix & FMD & $T 3$ & $y=4.49 x+55.94$ & $0.5543^{* * *}$ \\
\hline B5 & Robinia pseudoacacia (Locust) & Robinia & FMD & $T 3$ & $y=9.90 x-30.50$ & $0.773^{* * *}$ \\
\hline B6 & $\begin{array}{l}\text { Ligustrum compactum Ait } \\
\text { (Ligustrum) }\end{array}$ & Ligustrum & FMD & $T 3$ & $y=-4.15 x+411.48$ & $0.5648^{* * *}$ \\
\hline B7 & Citrus sinensis (Goose Orange) & Citrus & FMD & $T 3$ & $y=-4.72 x+429.36$ & $0.6295^{* * *}$ \\
\hline B8 & $\begin{array}{l}\text { Pterocarya stenoptera (Chinese } \\
\text { Wingnut) }\end{array}$ & Pterocarya & FMD & $T 3$ & $y=7.95 x+32.44$ & $0.9769^{* * *}$ \\
\hline B9 & $\begin{array}{l}\text { Broussonetia papyrifera (Paper } \\
\text { Mulberry) }\end{array}$ & Broussonetia & FMD & $T 3$ & $y=10.07 x-26.19$ & $0.7062^{* * *}$ \\
\hline $\mathrm{B} 10$ & Pittosporum tobira (Pittosporum) & Pittosporum & FMD & $T 3$ & $y=-6.72 x+470.03$ & $0.6289^{* * *}$ \\
\hline $\mathrm{B} 12$ & $\begin{array}{l}\text { Albizia julibrissin Durazz } \\
\text { (Albizzia) }\end{array}$ & Albizzia & FMD & $T 3$ & $y=9.38 x-7.98$ & $0.9041^{* * *}$ \\
\hline $\mathrm{B} 15$ & $\begin{array}{l}\text { Sophora japonica (Chinese } \\
\text { scholar tree) }\end{array}$ & Sophora & FMD & $T 3$ & $y=-7.20 x+480.48$ & $0.5147^{* * *}$ \\
\hline B16 & $\begin{array}{l}\text { Platycodon grandiflorus } \\
\text { (Bellflower) }\end{array}$ & Campanulaceae & FMD & $T 3$ & $y=-1.56 x+332.90$ & $0.3994^{* *}$ \\
\hline $\mathrm{B} 18$ & Ulmus parvifolia (Chinese Elm) & Ulmus & FMD & T3 & $y=-4.38 x+411.30$ & $0.4636^{* * *}$ \\
\hline B19 & Prunus salicina (Plum) & Prunus & FMD & $T 3$ & $y=5.97 x+68.11$ & $0.6569^{* * *}$ \\
\hline B20 & Podocarpus macrophyllus (Yacca) & Podocarpus & FMD & $T 3$ & $y=8.46 x+12.90$ & $0.8613^{* * *}$ \\
\hline B21 & Spiraea salicifolia (Spiraea) & Rosaceae & FMD & T3 & $y=4.54 x+66.98$ & $0.7922^{* * *}$ \\
\hline B24 & Malus pumila (Apple) & Malus & FMD & $T 3$ & $y=7.08 x+45.99$ & $0.752^{* * *}$ \\
\hline B25 & Vitis vinifera (Grapes) & Vitaceae & FMD & $T 3$ & $y=2.30 x+133.95$ & $0.3858^{* * *}$ \\
\hline B26 & $\begin{array}{l}\text { Acer buergerianum (Triangle } \\
\text { Maple) }\end{array}$ & Acer & FMD & $T 3$ & $y=8.66 x-0.14$ & $0.8935^{* * *}$ \\
\hline $\mathrm{B} 27$ & Morus alba (Mulberry) & Morus & FMD & $T 3$ & $y=7.39 x+29.03$ & $0.6055^{* * *}$ \\
\hline B28 & $\begin{array}{l}\text { Amygdalus davidiana (Mountain } \\
\text { Peach) }\end{array}$ & Rosaceae & FMD & $T 3$ & $y=2.06 x+129.26$ & $0.4054^{* *}$ \\
\hline B29 & Punica granatum (Pomegranate) & Punica & FMD & $T 3$ & $y=-7.23 x+465.29$ & $0.3348^{* * *}$ \\
\hline B30 & Amygdalus persica (Peach) & Rosaceae & FMD & $T 3$ & $y=2.19 x+126.46$ & $0.4828^{* * *}$ \\
\hline B31 & $\begin{array}{l}\text { Firmiana platanifolia (Chinese } \\
\text { parasol (tree)) }\end{array}$ & Firmiana & FMD & $T 3$ & $y=8.01 x+36.85$ & $0.4245^{* * *}$ \\
\hline B32 & $\begin{array}{l}\text { Cinnamomum camphora } \\
\text { (Camphor tree) }\end{array}$ & Cinnamomum & FMD & $T 3$ & $y=-7.57 x+475.66$ & $0.3458^{* * *}$ \\
\hline B34 & Platanus acerifolia (Planetree) & Platanus & FMD & $T 3$ & $y=-1.61 x+295.34$ & $0.2766^{*}$ \\
\hline B35 & Fontanesia fortunei (Fontanesia) & Fontanesia & FMD & T3 & $y=-9.59 x+526.56$ & $0.6768^{* * *}$ \\
\hline B36 & Cerasus pseudocerasus (Cherry) & Cerasus & FMD & $T 3$ & $y=-4.18 x+148.02$ & $0.7584^{* * *}$ \\
\hline B37 & Vernicia fordii (Tung tree) & Vernicia & FMD & T3 & $y=-1.61 x+343.40$ & $0.2597^{*}$ \\
\hline B38 & Firmiana simple (Phoenix tree) & Firmiana & FMD & $T 3$ & $y=10.26 x-31.01$ & $0.7707^{* * *}$ \\
\hline B39 & Cercis chinensis (Chinese redbud) & Cercis & FMD & $T 3$ & $y=9.13 x+2.45$ & $0.7293^{* * *}$ \\
\hline $\mathrm{B} 40$ & Wisteria sinensis (Wisteria) & Leguminosae & FMD & $T 3$ & $y=5.22 x+74.80$ & $0.7649^{* * *}$ \\
\hline B41 & $\begin{array}{l}\text { Lagerstroemia indica (Crape } \\
\text { myrtle) }\end{array}$ & Lagerstroemia & FMD & $T 3$ & $y=-4.37 x+402.51$ & $0.2792^{* *}$ \\
\hline B42 & Eriobotrya japonica (Loquat) & Rosaceae & FMD & T3 & $y=5.96 x+54.64$ & $0.3813^{* * *}$ \\
\hline B43 & Citrus maxima (Shaddock) & Citrus & FMD & T3 & $y=-5.54 x+422.98$ & $0.3158^{* *}$ \\
\hline
\end{tabular}


TABLE 3: Continued.

\begin{tabular}{|c|c|c|c|c|c|c|}
\hline Number & Species & Family & Phases & Air temperature & Fitting equation & $\operatorname{Adj.} R^{2}$ \\
\hline B44 & $\begin{array}{l}\text { Koelreuteria paniculata } \\
\text { (Goldenrain tree) }\end{array}$ & Koelreuteria & FMD & T3 & $y=-6.53 x+462.33$ & $0.6029^{* * *}$ \\
\hline B45 & Melia azedarach (Chinaberry) & Melia & FMD & $T 3$ & $y=-9.97 x+533.49$ & $0.6324^{* * *}$ \\
\hline
\end{tabular}

T3 denotes the average air temperature three months prior to fruit maturity date, where $*, * *$, and $* * *$ denote $10 \%, 5 \%$, and $1 \%$ significance levels, respectively.

with the rates being $5.30 \mathrm{~d} /{ }^{\circ} \mathrm{C}$ (Figure $4(\mathrm{a})$ ), $3.96 \mathrm{~d} /{ }^{\circ} \mathrm{C}$ (Figure $4(\mathrm{c})), 1.10 \mathrm{~d} /{ }^{\circ} \mathrm{C}$ (Figure $\left.4(\mathrm{~d})\right)$, and $3.35 \mathrm{~d} /{ }^{\circ} \mathrm{C}$ (Figure $4(\mathrm{e})$ ), respectively.

The opening dates for the Loquat Tourism Cultural Festival of Dazu District, Cherry Festival of Shuangshan Town, and Grape Tourism and Cultural Festival of Bishan District were found to be consistent with the trends in temperature variations. The dates were also aligned with the changing trends of FMD for the observed species (loquat, cherry, and grape, resp.) resulting from temperature changes. For the Jiangnan Loquat Festival (one of the other six festivals), half of its opening dates over the years remained scheduled on the weekends.

These findings indicate that most organizers of fruitpicking festivals did not take into account the effects of temperature changes when planning those events and that only a few activities were arranged to comply with changing phonological patterns of the related species. Most festival organizers have yet to consider the impact of CC on festival activities or have not paid adequate attention to the impact of temperature changes. Instead, they tended to simply schedule festival activities on the weekends.

\section{Conclusion and Discussion}

FPTA are essentially dependent on FMD. Although there has gradually been a consensus over the fact that CC affects plant phenology, the responses of different species to air temperature changes vary significantly. Some may even exhibit reactions opposite to regular patterns. In this study, 11 species that are directly related to FPTA were examined. Among them, the FMD for four species were advanced significantly, while the remaining 6-7 were significantly delayed. Specifically, pomegranate, apple, and mulberry were the most sensitive to temperature changes, while shaddock, peach, and cherry were the least sensitive. The implication is that the complexity of FPTA adaptation measures to CC has increased greatly. There is a need for researchers to examine each species individually to determine the trend and degree of sensitivity for each species' FMD in response to CC. In addition, even for the same species, the degree of phenological sensitivity to CC may vary significantly in different regions. Therefore, more comprehensive comparative analysis of case studies must be done to confirm the extent of CC's impact.

In recent years, more members of the public have gained a better understanding of CC and its impacts. It was found that prevailing temperatures for one or three months prior have a decisive influence on FMD. In order to adapt to CC, relevant management departments that operate FPTA should adjust the dates and durations of festival activities promptly based on changes in FMD or temperatures. However, this study found that very few festival organizers were aware of the impact of CC, nor have they adjusted festival opening dates according to dynamic temperature changes. A considerable number of festivals continue to fix the schedule of festival activities on the weekends. This will result in tourists missing out on the optimal fruit-picking season. The key to the further development of fruit-picking tourism is the provision of timely and accurate information on FMD to both tour operators and tourists.

There is a rich variety of FPTA around the world, most of which are vulnerable to CC's impact. However, there is a lack of existing phenological observations on species directly related to FPTA. Hence, it is necessary to increase the existing database of observations to include those species. The optimal season to carry out FPTA is between the time when fruits are beginning to ripen and that when they fall off the plants. The duration that each species' fruit maturity is sustained determines the period over which FPTA can be carried out. Existing phenological observation data contain more records on the timing when fruits begin to ripen, but there is a relative lack of records on the timing when fruits fall. This has in turn affected the accuracy of assessment studies on the impact of CC on FPTA.

In terms of the adaptability of fruit-picking tourism to CC, there is a need to establish phenological observation stations over a greater geographical distribution and a public platform for real-time dissemination of information. Presently, there are less than 40 observation stations in the whole of China. This is clearly insufficient to meet the needs of seasonal tourism activities. However, there is a lack of funds to establish large number of observation stations. In this regard, China can draw upon the experience of other countries by cultivating volunteers who make phenological observations and encouraging large-scale public participation through the setting up of a real-time phenology reporting mechanism. In addition, it is noted that China has yet to adopt a flexible vacation system. Even if festival organizers were to make real-time adjustments to event dates based on FMD and CC, visitors may not be able to participate due to the lack of leave. Thus the implementation of a flexible salaried vacation system which includes paid leave will be an important policy that will strengthen the adaptability of fruit-picking tourism to $\mathrm{CC}$ and ensure the sustainable development of the industry.

\section{Appendix}

See Tables 1, 2, and 3. 


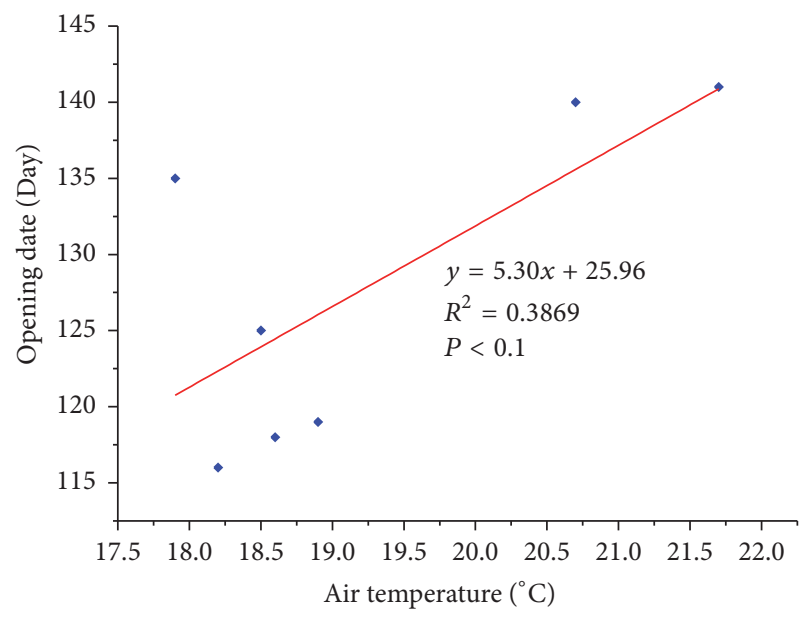

_ Fit curve

(a)

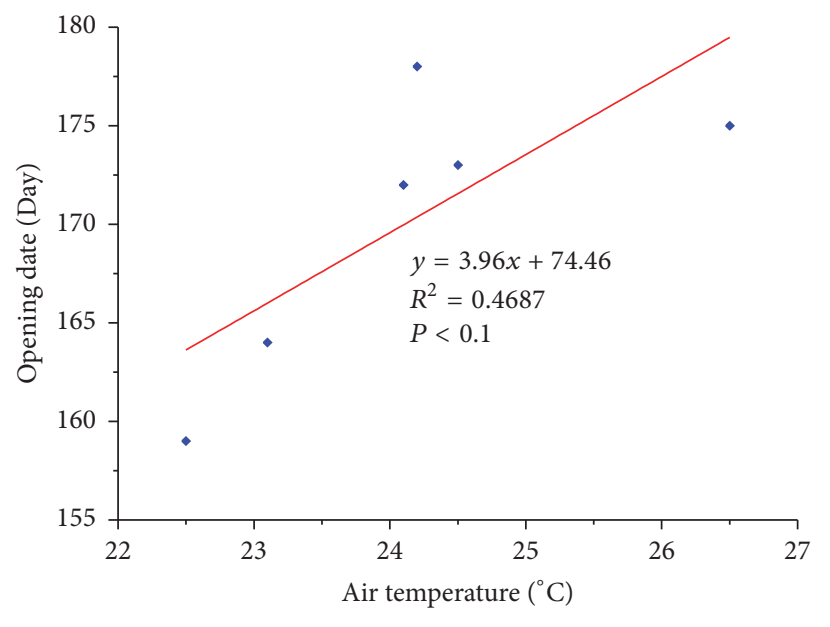

(c)

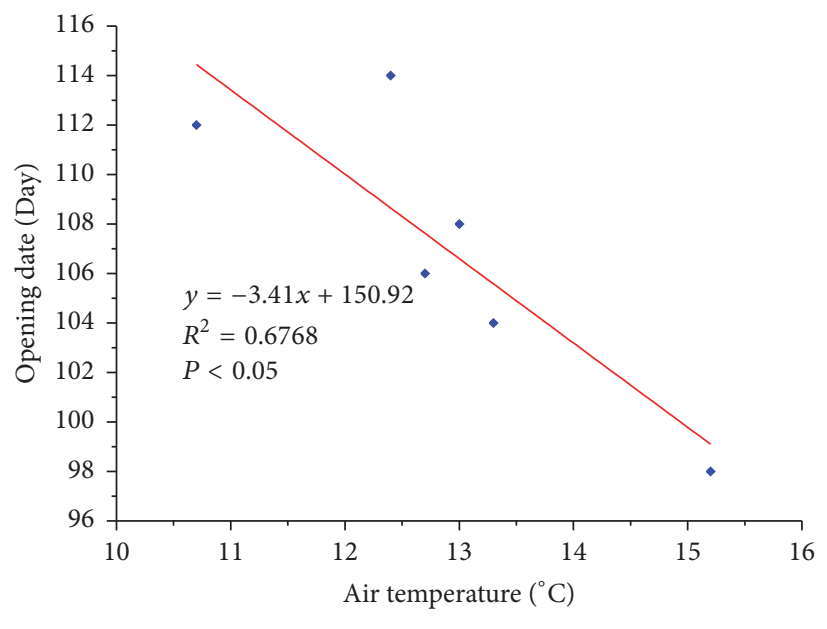

(b)

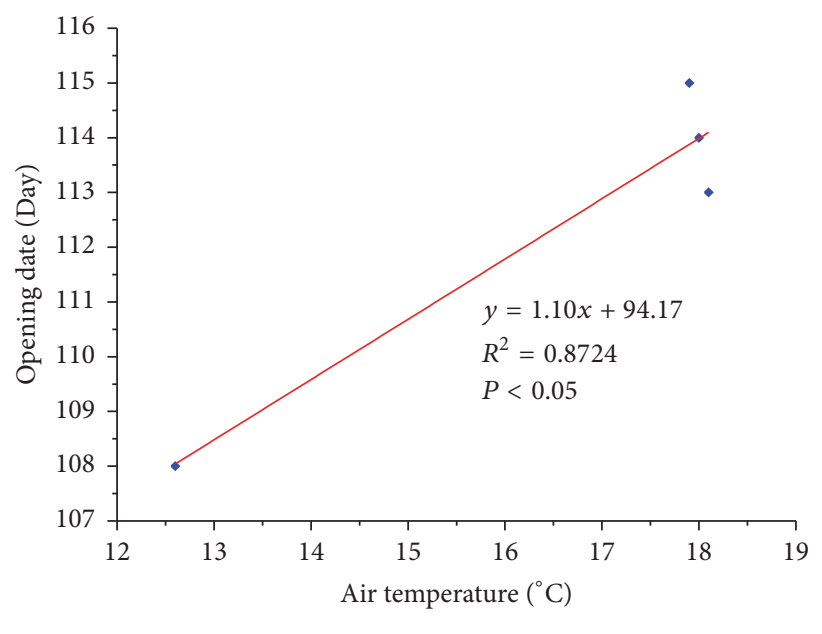

(d)

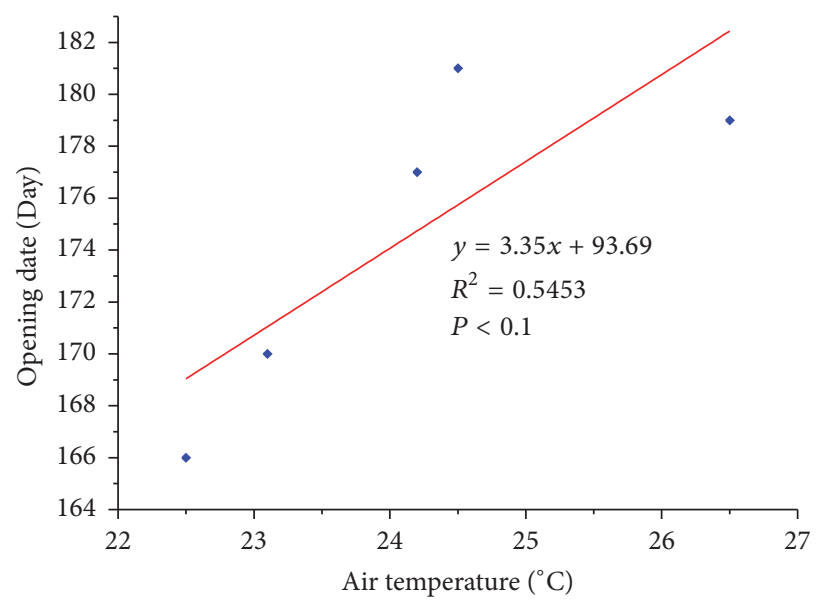

- Fit curve

(e)

FIGURE 4: Response relationship between picking tourism festival open date and air temperature in Chongqing. 


\section{Competing Interests}

The authors have declared that no conflict of interests exists.

\section{Acknowledgments}

This study was supported by the National Major Scientific Instruments and Equipments Development Project (Grant no. 41427805), the Ministry of Education of Humanities and Social Science Project (Grant no. 16YJC790060), Social Science Planning Annual Project of Sichuan, China (Grant no. SC15B046), Soft Science Research Project of Sichuan, China (Grant no. 2015ZR0225), and the Fundamental Research Funds for the Central Universities (Grant no. skqy201639).

\section{References}

[1] P. P. Mohanan, "Cardiology blooms at ACC 2014 at Washington DC but no cherry blossoms," Indian Heart Journal, vol. 66, no. 2, pp. 253-254, 2014.

[2] L. Wang, H. Chen, Q. Li, and W. Yu, "Research advances in plant phenology and climate," Acta Ecologica Sinica, vol. 30, no. 2, pp. 447-454, 2010.

[3] X. Yunjia, D. Junhu, W. Huanjiong et al., "Variations of main phenophases of natural calendar and analysis of responses to climate change in Harbin in 1985-2012," Geographical Research, vol. 34, no. 9, pp. 1662-1674, 2015.

[4] B. Jie, G. Quansheng, and D. Junhu, "Response of woody plant phenophases to climate change for recent 30 years in Guiyang," Geographical Research, vol. 28, no. 6, pp. 1606-1614, 2009.

[5] C. M. Hall, "Tourism and biodiversity: more significant than climate change?" Journal of Heritage Tourism, vol. 5, no. 4, pp. 253-266, 2010.

[6] M. Li and F. Xiuqi, "Effect of global warming on seasonal tourism for the last 20 years in Beijing: a case study on the peach flower stanza of Beijing Botanical Garden," Advance in Earth Science, vol. 21, no. 3, pp. 313-319, 2006.

[7] R. Sakurai, S. K. Jacobson, H. Kobori et al., "Culture and climate change: Japanese cherry blossom festivals and stakeholders' knowledge and attitudes about global climate change," Biological Conservation, vol. 144, no. 1, pp. 654-658, 2011.

[8] L. Jun, L. Yunyun, L. Haolong et al., "Climate change and peach blossom viewing: impact and adaptation," Geographical Research, vol. 35, no. 3, pp. 504-512, 2016.

[9] Q. Ge, J. Dai, J. Liu, S. Zhong, and H. Liu, "The effect of climate change on the fall foliage vacation in China," Tourism Management, vol. 38, pp. 80-84, 2013.

[10] Y. Aono and K. Kazui, "Phenological data series of cherry tree flowering in Kyoto, Japan, and its application to reconstruction of springtime temperatures since the 9th century," International Journal of Climatology, vol. 28, no. 7, pp. 905-914, 2008.

[11] W. He, R. Bu, Z. Xiong, and Y. Hu, "Characteristics of temperature and precipitation in Northeastern China from 1961 to 2005," Acta Ecologica Sinica, vol. 33, no. 2, pp. 519-531, 2013.

[12] L. Guangsheng, W. Genxu, H. Hongchang et al., "Climate change characteristics in the source regions of the Yangtze River and Yellow River over the past 45 years," Resources Science, vol. 32, no. 8, pp. 1486-1492, 2010.

[13] C. Torrence and G. P. Compo, "A practical guide to wavelet analysis," Bulletin of the American Meteorological Society, vol. 79, no. 1, pp. 61-78, 1998. 

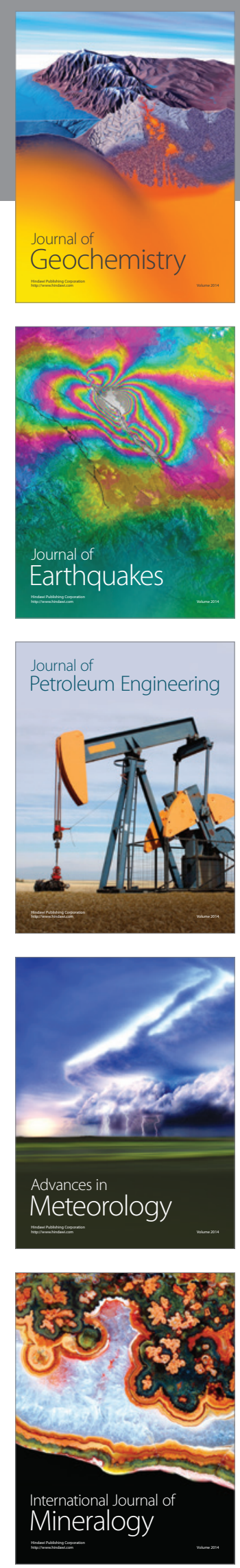
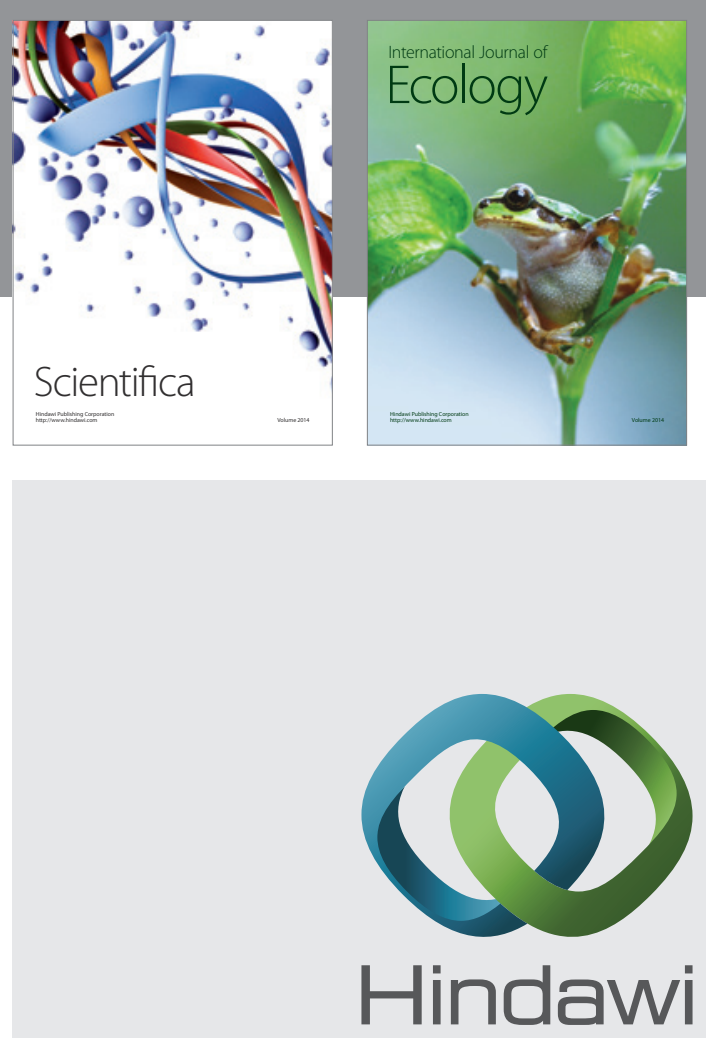

Submit your manuscripts at

http://www.hindawi.com
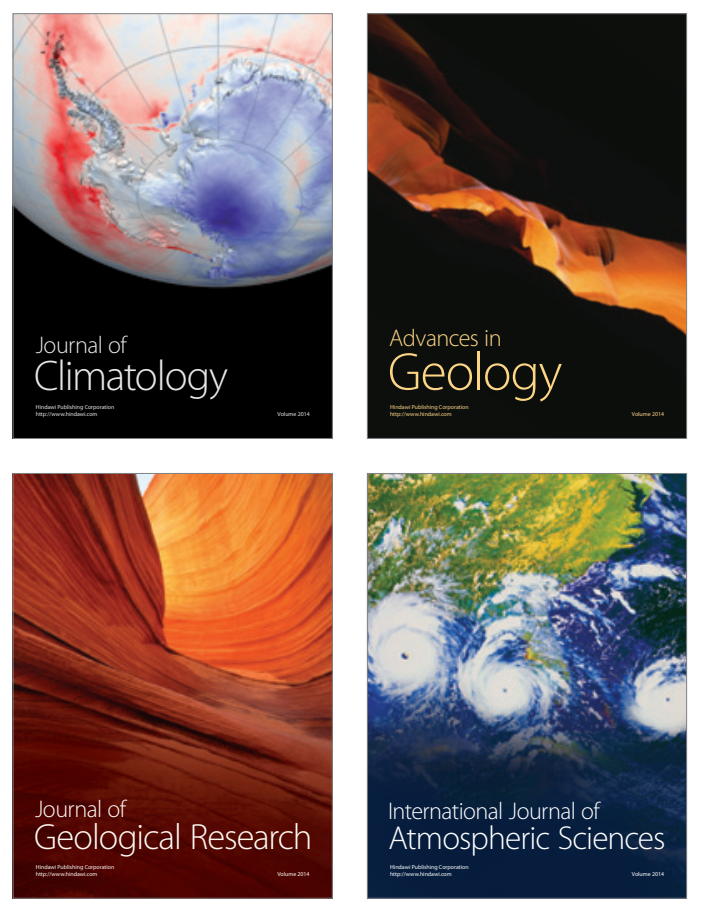

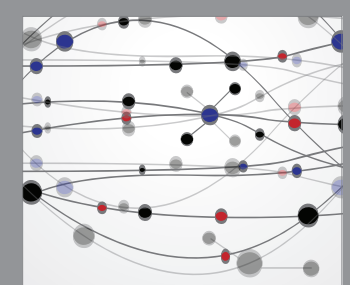

The Scientific

\section{World Journal}
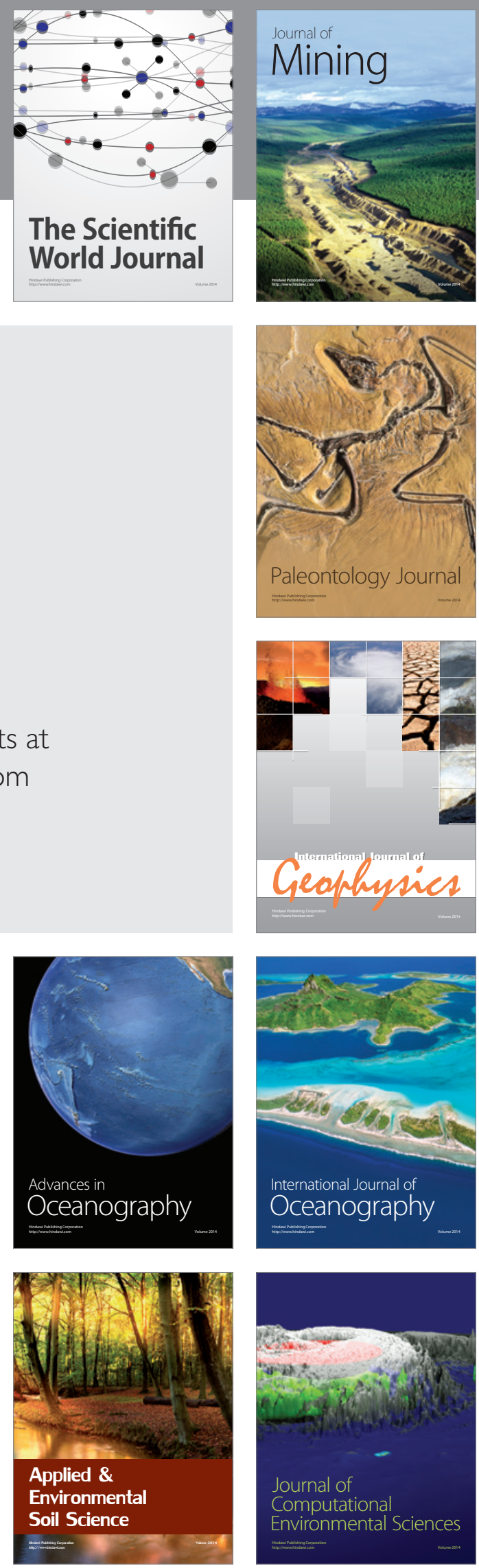